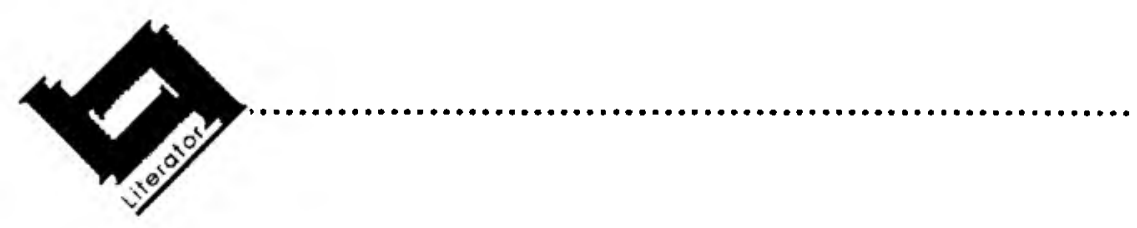

\title{
Verhale oor die Anglo-Boereoorlog
}

\author{
C.N. van der Merwe \\ Departement Afrikaans en Neerlandistiek \\ Universiteit van Kaapstad \\ KAAPSTAD \\ E-pos: cnvdm@beattie.uct.ac.za
}

\section{Abstract}

\section{Fiction on the Anglo-Boer War}

This article gives an overview of fictional prose about the Anglo-Boer War of 1899-1902. In contrast to the desire of many people to "forgive and forget" this past war, some authors for example Gustav Preller and D.F. Malherbe, told stories to remind the reader of the suffering of the past. Stereotypical patterns in a number of conventional war stories are mentioned in the article, followed by a discussion of fictional texts deviating from these conventional patterns - inter alia, works by Johannes van Melle and J.R.L. van Bruggen. In conclusion, texts are analysed which use the war experience to illuminate the general human condition: works by Etienne Leroux, Elsa Joubert and others.

\section{Inleiding}

Die hedendaagse Afrikaanse prosa "word gekenmerk deur 'n bykans obsessionele belangstelling in en bemoeienis met die persoonlike en kollektiewe geskiedenis" - so merk H.P. van Coller (1997:11) op in 'n nommer van Stilet waarin die verhouding tussen die Afrikaanse letterkunde en die Suid-Afrikaanse geskiedenis sentraal staan. Hierdie gerigtheid op die geskiedenis hang saam met die politieke veranderinge in die negentigerjare, wat volgens J.P. Smuts (1997:6), in dieselfde nommer van Stilet, "moontlik die grootste grens in die geskiedenis van Suid-Afrika" is.

Honderd jaar gelede het die land ook gestaan op die drumpel van 'n eeuwenteling en van 'n gebeurtenis wat alle inwoners van die land ingrypend sou beïnvloed: die Anglo-Boereoorlog van 1899-1902. Die doel van hierdie artikel is om 'n oorsig te gee oor die uitbeelding van hierdie gebeure in die Afrikaanse verhalende prosa 
sedertdien, en om daardeur lig te werp op aspekte van die verhouding tussen fiksie en geskiedenis, en die verwerking van 'n traumatiese verlede in die literatuur - kwessies wat vandag besonder aktueel is. Die artikel streef nie na volledigheid nie, maar na die aanduiding van 'n aantal opmerklike tendense.

\section{Vergeet (nie)}

Die eerste wat 'n mens opval by die nagaan van die verhalende prosa oor die Anglo-Boereoorlog, is die relatiewe skaarste van verhale. Daar was wel 'n uitstorting van poësie oor die Oorlog; maar, in vergelyking met byvoorbeeld die neerslag van die Tweede Wêreldoorlog in die Nederlandse prosa, toon die Afrikaanse verhalende literatuur 'n verstommende prosadroogte oor dié onderwerp. Oor die jare het die Groot Trek veel meer stof vir verhalende prosa opgelewer; miskien omdat dit meer geskikte materiaal bevat het vir die skep van 'n volksmite - 'n eksodus met Bybelse konnotasies. Wel moet 'n mens noem dat sekere jeugboeke oor die Anglo-Boereoorlog baie gewilde leesstof was, byvoorbeeld Fritz Steyn se Die Penkop-kommando (1941) en Die ruiter in die nag (1964) deur Mikro. Danie van Niekerk, vroeër hoof van Tafelberg-Uitgewers, het in 'n gesprek vertel dat laasgenoemde boek in die jare dat hy by Tafelberg gewerk het, nooit uit druk was nie.

In 'n bydrae tot die Christiaan de Wet-annale wys J.F. Stemmet op die vloed van dagboeke en herinneringe oor die oorlog wat tussen 1900 en 1905 verskyn het twee-en-twintig in totaal (Stemmet, 1975:108). Die oes aan fiksie oor die Oorlog was egter in dié tyd onbeduidend. Direk na die vredesluiting was die ervaring van die Oorlog waarskynlik nog te rou om dit te omskep in stories van die verbeelding; die dwingende behoefte was om sonder sulke "versiering" direk te vertel wat ondervind is. Dit is egter verbasend dat, oor latere dekades heen, so 'n boeiende stuk geskiedenis so relatief min literêre prosa opgelewer het.

Een van die redes hiervoor mag wees dat sommige mense gevoel het dat die oorlogsgeskiedenis 'n verdelende uitwerking op die samelewing het en daarom liefs met rus gelaat moes word. Vir baie jare na die oorlog was daar 'n debat tussen "onthou" en "vergewe en vergeet"; anders gestel, tussen "waarheid" en "versoening". J.C. Steyn skryf boeiend oor hierdie debat in die artikel "Blouvitrioel of sopkombuise?" (Steyn, 1987:191-206, veral p. 191, 202-205). Steyn vertel onder andere van 'n briefskrywer wat in 1938 in Die Vaderland gevra het vir 'n verbod op boeke soos 'n Merk vir die eeue van T.C. Pienaar, omdat hierdie verhaal oor die lyding in die konsentrasiekampe volgens die skrywer aanstoot kon gee aan 'n deel van die Suid-Afrikaanse bevolking. Verdere pleidooie vir vergewe en vergeet, vermeld in Steyn se bespreking, was genl. Louis Botha se toespraak aan die einde van die Rebellie en ook die brief van "Fiat Justitia" in Die Burger in 1938. Stemmet, in sy genoemde artikel, noem die konsiliasiebeleid 
van Botha en Smuts tussen 1906 en 1931 as 'n rede vir die kwynende belangstelling in die Oorlog (Stemmet, 1975:111-2).

Daar was 'n jarelange debat tussen diegene wat die traumatiese verlede wou vergeet, en diegene wat wou onthou. P.C. Schoonees was een van dié wat die verlede wou onthou, soos blyk uit sy bespreking van Ons parool deur Gustav Preller. Hy prys Preller se vermoë om "gebeurtenisse wat al verdof het in die wasige verlede (...) te laat herrys ... Dat Preller dit bereik het, bly vir my die vemaamste aantreklikheid van sy verhaal, veral as ek dink aan soveel ander oorlogsherinneringe wat so duidelik die merkteken dra van die leer van "vergewe en vergeet"' (Schoonees, 1939:531).

Die geskrifte wat die verlede lewend wou hou, was wel min in aantal, maar het met verloop van tyd groter bekendheid verwerf as dié wat wou vergewe en vergeet. In my eie ondersoek kon ek byvoorbeeld nie agterkom na watter werke Schoonees verwys wat die gesindheid van vergewe en vergeet predik nie; daarenteen was dit nie moeilik om die werke op te spoor wat die verlede lewend wou hou nie.

Een van die laasgenoemde kategorie was Gustav Preller se Oorlogsoormag en ander sketse en verhale (1923). Die skrywer begin die openingsverhaal "Lettie" met die woorde: “... (ek) dag dat dit liewer nou moes opgeteken word, anders gaan alles nog dalk verlore. Die hele oorlog dof al so langsamerhand weg uit ons herinnering ... om 'n kleurlose politiek te behaag" (Preller, 1923:3).

Dit is by Preller moeilik om fiksie en feite te onderskei en dit is duidelik dat die verhale ten minste gedeeltelik verband hou met die skrywer se eie oorlogservaringe. Schoonees wys daarop dat die verhale vertel word met die egtheid van iemand wat alles self meegemaak het, maar dat dit deur die verbeelding omskep is, sodat die klem val op die menslike kant van die oorlog (Schoonees, 1939:525). Die vertellings bestaan nie uit blote idealisering van die Boerekrygers nie. Veral in die titelverhaal is daar ' $n$ besonder mooi balans tussen die heldhaftigheid en vernuf van die Boerekrygers, en die gevoel van moedeloosheid ondanks die Boereprestasies.

Nog 'n skrywer wat die oorlogsverlede nie aan die vergetelheid wou oorgee nie, was D.F. Malherbe, wat die geskiedenis wou gebruik om die Afrikaner-nasie as 'n groep in stand te hou - 'n groep gebind deur 'n gemeenskaplike verlede van lyding. Dit spreek duidelik uit Vergeet nie.

Dié roman is gepubliseer in 1913, dus kort na die totstandkoming van die Unie van Suid-Afrika. Moontlik was D.F. Malherbe bevrees dat unifikasie, gepaard met ' $n$ beleid van rekonsiliasie met Engeland en versoening tussen Afrikaans- en Engelssprekendes, die Afrikaners se groepsidentiteit sou ondermyn. Malherbe wil 
die gemeenskaplike verlede van alle Afrikaners in die Unie as bindende faktor beklemtoon; daarom skep hy karakters uit die Kaap wat deelneem aan die AngloBoereoorlog en wat onder die oorlogsverdrukking ly, saam met hul volksgenote uit die Boererepublieke. Piet Marais, 'n geneesheer uit die Kaapkolonie wat die gewonde Boeresoldate op die slagveld help, sê: "Ek is nie Transvaler, ook nie Vrystater nie, maar Afrikaner (...) ons veg vir die behoud van die Afrikanernasie" (p. 58). Hierdie groepsidentiteit moet lewend gehou word deur die onthou van die verlede, en daarom word die woorde "vergeet nie" as titel gebruik, en ook in die roman drie keer kort na mekaar gesê, in skuinsdruk (p. 157). Die boodskap is duidelik.

\section{Stereotiepe patrone}

In die dertigerjare, saam met 'n oplewing van Afrikaner-nasionalisme, begin 'n sterk toename in die publikasie van dagboeke oor die Oorlog (Stemmet, 1975: 118). Die fiksie bly egter nog agter, hoewel daar in die dertigerjare 'n geringe oplewing van die tema is. Miskien het dit te make met die populariteit van verhale oor die Anglo-Boereoorlog wat in dié tyd in Die Huisgenoot verskyn het, en wat die belangstelling in die oorlog heraktiveer het. (Vergelyk hieroor die herinneringe van die oud-redakteur van Die Huisgenoot, Marcus Viljoen 1953:115-116.)

Oorlogsromans uit die dertigerjare sluit onder andere die volgende in: ' $n$ Wiel binne ' $n$ wiel van Miemie Louw-Theron (1935); T.C. Pienaar se 'n Merk vir die eeue (1937); J.R.L. van Bruggen se Bittereinders (1935 - met 'n sterk historiese basis, 'n vroeë voorbeeld van "faction"); ook die kortverhaal "Jaap kan nie verstaan nie" uit Steiltes van G.J. Joubert (1938) en N.P. van Wyk Louw se "Oorlogstories", gepubliseer in Die Jongspan van 4 Maart 1938.

Hierdie verhale is van min literêre betekenis, soos ook die volgende wat voor die dertigerjare verskyn het: Deur die smeltkroes van Gordon Tomlinson (1917); Wraak van Joubert Reitz (1927); en Die tweede Grieta van J.H.H. de Waal (1912). 'n Patroon wat hier steeds terugkeer, is dié van die skurkagtige joiner en die heldhaftige bittereinder wat meeding om die guns van die fraaie Boeremeisie; en dis die bittereinder wat ten slotte met die meisie beloon word. Skuld en onskuld word simplisties teenoor mekaar gestel; die verhale is 'n aanklag teen die onreg van die oorlog, en fokus sterk op die leed van die konsentrasiekampe. 'n Voorbeeld van 'n boek waarin die konsentrasiekamp-gebeure die aandag ontvang, is Helkampe van Ewald Steenkamp wat tydens die Tweede Wêreldoorlog verskyn het (1941) en op grond van landsverdediging-oorwegings deur die regering verbied is. (Vir meer besonderhede, onder andere kritiek deur historici op die boek, vgl. Steyn, 1992:90,92.) 
By die patroon van die slegte joiner en die goeie bittereinder sluit Teleurgestel (1918) van Jochem van Bruggen gedeeltelik aan, maar deur die simpatieke uitbeelding van Stols, 'n "jabroer van die beste soort" (124), word die stereotiepe patroon tog deurbreek. Stols is 'n goedige siel wat van nature nie in staat is om heldhaftig en trou te wees nie, en deur die simpatie met hom word die blaam grotendeels opgehef.

In bogenoemde stereotiepe leesstof word die gangbare Afrikaner-denke oor die oorlog, oor morele skuld en Afrikaner-heldedom weergegee en bevestig. Dit is met hierdie konvensionele denke en uitbeelding dat enkele skrywers in gesprek tree.

\section{Die gesprek met die dominante tradisie}

\subsection{Johannes van Melle}

Een so 'n skrywer is Johannes van Melle. Besonder relevant in hierdie opsig is sy lang kortverhaal "Wraak", wat in 1943 in die bundel Begeestering verskyn het. Dit handel oor die stryd van die boer Berend Viviers om sy bywoner te vergewe wat in die oorlog 'n joiner was en sy (Berend se) seun doodgeskiet het. Berend is 'n voorbeeldige Christen, en hy wil vergewe, soos wat die Bybel voorskryf, maar hy kan nie - veral nie wanneer die bywoner na die oorlog, met Berend se toestemming, weer op die plaas kom woon nie. Die spanning in sy gemoed tussen vergewe en onthou, tussen versoening en geregtigheid, bereik dan 'n breekpunt.

Omdat Berend se Christelike gewete hom nooit sal toelaat om sy diep-gesetelde wraakbegeerte te bevredig deur moord op sy bywoner te pleeg nie, neem die psige 'n nood-uitvlug. In 'n tydelike verval in waansin, waarin Berend hom verbeel dis weer oorlog, skiet hy sy bywoner dood. Hiermee word Berend se teenstrydige verlangens vervul: die eise van die gewete is deur die "oorlogsituasie" ontduik én sy onderdrukte wens vir geregtigheid is vervul.

Tipies van Van Melle, is hier geen skurk-held-teenstelling nie. Sowel die bittereinder Berend as die joiner-bywoner word met simpatie geteken; albei met foute sowel as goeie punte. Die bywoner het gruwelik gesondig in die oorlog, maar hy het berou en bely sy skuld. Berend is wel 'n voorbeeldige Christen en Afrikaner, maar in sy vergiffenis-ideaal dryf hy homself verby die perke van menslikheid om die onmoontlike te bereik. Sy dryfveer is in werklikheid hoogmoed, en deur sy hubris bring hy 'n ramp op homself en sy naaste.

Die skuld van die joiner word by Van Melle die skuld van die mens; hierby is volksverraad sowel as heimlike hoogmoed ingesluit. (Vir meer besonderhede oor die oorlogsverhale van Van Melle, vgl. Van der Merwe, 1998.) 


\subsection{J.R.L. van Bruggen (Kleinjan)}

In 1942 verskyn Die gerig, 'n roman deur J.R.L. van Bruggen (Kleinjan). Dit handel oor die botsing tussen ' $n$ man en sy vrou en sluit aan by die werk van Van Melle, veral by sy roman, Bart Nel, wat in 1936 (grotendeels) in Nederlands verskyn het onder die titel Bart Nel, de opstandeling, en in 1942 in Afrikaans onder die titel En ek is nog hy.

Anders as die gewone konflik in oorlogsromans tussen twee manlike karakters, die hensopper en die bittereinder, is die sentrale stryd hier tussen 'n teruggekeerde bittereinder-balling en sy "hensopper"-vrou wat tydens sy ballingskap intiem bevriend geraak het met 'n Engelse offisier. Deur haar vriendskap met die Engelsman is hulle huis nie afgebrand nie en het meubels uit hul bure se afgebrande huise in hulle woning beland.

Die konvensionele patroon sou wees dat die man bewonderenswaardig en sy vrou verfoeilik is, maar hier is dit hoegenaamd nie die geval nie. Die vrou (Hanna) het gedink dat haar man (Giel) op die slagveld gesneuwel het, en daar is dus by haar geen sprake van 'n owerspelige verhouding met die Engelsman nie - die verhouding met die Engelse offisier is in elk geval niks meer as blote vriendskap nie. Wanneer haar man terugkom, het sy haarself egter heeltemal aangepas by 'n nuwe, "elegante" lewenstyl volgens Engelse modes, en dit voel vir haar of 'n muur tussen haar en haar "eenvoudige" Afrikanerman verrys het.

Soos in Bart $\mathrm{Nel}$, wissel die fokus reëlmatig tussen die twee hoofspelers in die proses van vervreemding. Man en vrou, in hierdie "oorlog van die geslagte", word elk in eie reg uitgebeeld. Daar is simpatie vir Hanna, vir wie haar man 'n vreemdeling geword het, maar ook vir Giel, wanneer hy teenoor die Engelse offisier uitwei oor die bedreiging wat die Britse mag en kultuur vir die Afrikaner inhou (Van Bruggen, 1943:172-180).

Hanna, in haar reaksie op Giel se argument, openbaar 'n gebrekkige kennis van die geskiedenis (p. 180), en die leser neig in hierdie stadium om Giel se kant te kies. Dan verander die leser se houding egter. Anders as in Bart Nel, waar die man uiteindelik in morele opsig die meerdere van sy vrou is, is dit hier die vrou wat mettertyd die meeste simpatie verdien. Ondanks die feit dat Hanna telkens haar man sy sin gee, word hy nie verteder nie. Hy begin met 'n stelselmatige veldtog van wraak op haar, en deel haar klere bietjie vir bietjie aan die bediendes uit. Vir hom is enige materiële welvaart 'n skandelike teken van haar volksontrou en haar vriendskap met die Engelse vyand. Giel sê aan Hanna: "God het my die instrument gemaak om jou te kasty vir jou sondes" (p. 205). Sy woede en veroordeling is besig om hom van sy sinne te beroof. 
In haar eensaamheid soek Hanna nou toenadering tot Liesbet, die bediende. Rasverskil word minder belangrik as die gemeenskaplike lot van die vrou - 'n heel vroeë feministiese aanslag, deur 'n manlike skrywer! Giel veroordeel hierdie toenadering en Hanna, volkome versmoor deur haar man, soek na algehele bevryding. Sy verlaat hom en gaan terug na haar ouers in Bloemfontein. Hier wil sy weer opgaan in die stedelike leefwyse wat sy deur haar Engelse vriend leer waardeer het - vry van haar man en vry van sy Afrikaner-plaaskultuur.

Hanna ervaar egter dat die Engelse vriend tog nie die staatmaker is wat sy gedink het nie, en besluit later om na haar man terug te keer. Op dieselfde tyd dat sy 'n versoenende brief aan hom pos, sterf hy egter in 'n brand. Die verbitterde Giel het uiteindelik totaal waansinnig geraak: hy het sy huis afgebrand omdat hy die ongeskonde huis beskou het as 'n bewys van sy vrou se volksverraad; in hierdie brand sterf hy self ook. Sy bitterheid en wraak het homself uiteindelik vernietig.

Hoewel hierdie boek, 56 jaar na publikasie, nog so eietyds aandoen, het dit vandag grotendeels vergete geraak.

\subsection{Eugéne Marais}

By Marais, wat 'n hele aantal verhale oor die Anglo-Boereoorlog gepubliseer het, gaan dit nie om kwessies soos die lydingsgeskiedenis van die Afrikaner, die skuld van die Engelse of die opbloei van Afrikaner-nasionalisme nie. Sy verhale is bowenal joernalisties van aard, en die doel daarvan is om die leser te vermaak. Hy fokus op buitengewone ervarings: wat hy vir waarheid aanbied, lyk dikwels bra na 'n liegstorie. Deur sy ideologiese neutraliteit neem hy miskien juis 'n ideologiese posisie in - 'n anti-nasionalistiese houding.

'n Voorbeeld ter illustrasie: die verhaal "Afrikanerbeeste" uit Die leeus van Magoeba (1934). Een van die karakters is 'n uitmuntende Boereverkenner, Gool Winterbach; maar hy is nie die hoofkarakter nie. Die rol van hoofkarakter en held word gedeel deur die Boesman Hendrik, 'n veldkenner wat selfs vir Gool in die skadu stel, en die slim Afrikaner-beeste, wat so getrou op die bevele van Hendrik reageer. Die Boereheld word na die kantlyn geskuif om die sentrale posisie aan die Boesman te gee en die verteller word meer geboei deur Afrikaner-beeste as Afrikaner-helde.

\subsection{Leipoldt}

As jong skrywer het Leipoldt twee verhale in Nederlands geskryf wat 'n felle aanklag teen die oorlog gemaak het: "De rebel" en "Bambinelino". Albei het in Elseviers Geillustreerd Maandblad verskyn - in Desember 1900 en November 1901 onderskeidelik. (Vir verdere besonderhede hieroor, kyk Du Toit, 1948:262270.) In latere jare, toe Leipoldt die versoeningspolitiek van Louis Botha gesteun 
het, het hy die oorlogstema met sy potensiele nasionalistiese konnotasies vermy. By hom, nog duideliker as by Marais, was die stilte oor die oorlog 'n veelseggende stilte.

\section{Veralgemening van die oorlogservaring}

Veral in latere verhale oor die Anglo-Boereoorlog, uit tye dat die intensiteit van die emosies oor die oorlog afgeneem het, gaan dit nie soseer oor die oproep van historiese gegewens nie as om die gebruik van die geskiedenis vir die uitbeelding van temas van 'n algemene menslike aard.

\subsection{Droom en werklikheid}

Die oorlog vorm die agtergrond van twee pragtige verhale van Toon van den Heever: "Die beukelaar van outa Sem" en "Outa Sem en Vader Krismis" - albei uit Gerwe uit die erfpag van Skoppensboer (1948). Albei handel oor 'n kind wat alleen op die plaas agtergebly het omdat sy vader en broers aan die oorlog deelneem en sy moeder oorlede is. Hy word opgepas deur twee troue Griekwas, "outa" Sem en sy vrou Koema. Deur die Griekwa-karakters wys die skrywer op die swaarkry en die trou van swart mense tydens die Oorlog en herinner hy daaraan dat dit nie 'n oorlog van blankes alleen was nie.

Historiese gegewens is in hierdie twee verhale egter nie van primêre belang nie, maar eerder die bobaas-vertellings van Sem met sy komiese taalgebruik, en die algemene menslike ervaring wat na vore kom. "Gods Roberts", 'n kostelike verbinding van "Lord Roberts" en die uitroep "Gods!", word in "Die beukelaar van Outa Sem" die simbool van alles wat die mens bang maak en bedreig. Sem sit vir "Gods Roberts" in sy verbeeldingryke stories op sy plek; maar uiteindelik, as die werklike aanslag van die Engelse soldate op die plaas kom, moet die verbeelding die wyk neem voor die skrikwekkende realiteit, en Sem sit op loop.

In "Outa Sem en Vader Krismis" vertel Sem hoe hy vir Vader Krismis uit die moeilikheid gehelp het met 'n "briljante" plan: 'n wa deur die lug getrek deur miskruiers. Die lyn wat die wa volg, 'n styging gevolg deur 'n daling, stel grafies die tema voor van 'n verbeeldingsvlug gevolg deur ontnugtering. En tog, Sem se bedagsaamheid om darem iets in die seun se Kerssak te sit, al is dit nie alles wat sy hart begeer nie, en ook sy betowerende storie oor die Kersgeskenk, maak van hierdie oorlogskersfees veel meer as die saaie dag wat dit andersins sou gewees het.

\subsection{Die sin van lyding}

Die tema van die sin van lyding is reeds in baie van die vroeë oorlogsverhale aanwesig: die verlies van onafhanklikheid by die Vrede van Vereeniging het, 
meer nog as die oorlogsmart, vrae oor die beskikking van God opgeroep. In 'n Wiel binne 'n wiel (1935) van Miemie Louw-Theron word, na aanleiding van Esegiël 1:16, tot die gevolgtrekking gekom dat die mens nie die onbegryplike plan van God kan deurskou nie. Maar dan, teenstrydig met hierdie gedagte, word die rede tog gegee waarom God die Afrikaners so laat ly het: hulle moes naamlik leer om saam te staan in plaas van soveel te twis.

Veel meer gekompliseerd word die tema behandel in "Vrede" van J.C. Steyn, uit Op pad na die grens (1976). Die gebeure tydens die oorlog en die verlies van onafhanklikheid daarna suggereer 'n totaal sinlose verloop van die geskiedenis, en die verteller, 'n jong Afrikanerseun, verval dan ook in 'n totale pessimisme en sinisme. Hierin word hy gesteun deur Meester, die onderwyser wat so baie weet. Teenoor hulle staan die gelowige lotsaanvaarding van die verteller se ouers, wat aan hulle vrede verleen te midde van hul teenspoed. Die "vrede" van die titel is meerduidig: vrede het wel aangebreek, maar dis nie 'n vrede wat bevryding vir die Afrikaner bring of gemoedsrus omdat geregtigheid geskied het nie. In die verteller se gemoed is daarom geen vrede nie, maar onvrede, maar vir die ouers is daar 'n innerlike standhoudende vrede.

Hoewel die verhaal nie duidelik kant kies vir een van die twee kontrasterende houdings nie, is dit tog betekenisvol dat daar ' $n$ verandering by die verteller te bespeur is - hy noem ten slotte die moontlikheid dat God dalk troos - al stel hy dit in 'n aarselende vraagvorm - en hy bid tot God om ontferming. Hy self het nie die vrede van sy ouers nie, maar dit is waarna hy verlang.

Ook in die magistrale Die reise van Isobelle (1995) van Elsa Joubert word die oorlogsleed verbind met die vraag na die sin van lyding. Dominee Josias van Velden, die hoofkarakter van die eerste deel van die roman, besoek die konsentrasiekamp by Springfontein en kom diep onder die indruk van die smart van die vroue en kinders. Die besoek word egter vir hom ook 'n verheffende ervaring, omdat dit hom tot egte mededoë beweeg, tot 'n byna mistieke eenwording met die lydendes: "Die ervaring in die kamp (...) is vir hom skoner, mooier, heiliger as enigiets wat hy tot nog toe ervaar het. Ons is saam die liggaam van Christus, die lydende mens teenoor wie Hy so 'n mededoë had" (p. 47).

Ook die dood van die godvresende tant Hester Prinsloo word vir hom 'n sinryke gebeurtenis. Wanneer sy sterf, vul die geur van soetemalings die tent, en tant Hester kry 'n visioen van 'n engelemenigte wat om hulle vergader. Dit lyk of hierdie episode bevestig wat ook elders in die boek gesuggereer word, naamlik dat lyding die prys is vir die mistieke verbintenis met God: "Is lyding die prys van die Godsbewussyn? dink hy toe hy na sy tent toe loop. Is dit dan tog waar dat lyding die instrument is waarmee God sy kinders na Hom toe bring?' (p. 46). 


\section{6. 'n Eietydse mite}

Waarskynlik die verbeeldingrykste verwerking van die Anglo-Boereoorlog tot roman is te vinde in Magersfontein, o Magersfontein! (1976) van Etienne Leroux, wat handel oor 'n buitelandse filmspan wat die historiese slag van Magersfontein kom verfilm. Met hierdie gebeure beeld Leroux die argetipiese stryd tussen die wit nar en die swart nar uit; dit wil sê, tussen die ordelike, rasionele kant van die menslike psige en die "skadukant", die irrasionele, spontane kant wat die orde uitdaag.

Volgens hierdie roman was die basiese konflik by die Slag van Magersfontein nie dié tussen Boere en Engelse nie, maar tussen wit en swart narre aan albei kante. Genl. Cronjé en lord Methuen is die wit narre, en genl. De la Rey en Wauchope is die swart narre. Dit wil voorkom of die simpatie van die skrywer veral by die onderdrukte swart nar lê, want die Slag van Magersfontein word deur die Boere gewen omdat, soos die roman dit sien, aan die Engelse kant die wit nar die botoon in die beplanning gevoer het, terwyl aan die Boerekant die geniale De la Rey se plan deurgevoer is in plaas van dié van die meer konvensionele Cronjé Wauchope, soos die reus in Een vir Azazel (1964), is die onskuldige sondoffer van die kunsmatige orde van die wit nar. Die held Wauchope is egter nie 'n simplistiese swart of wit nar nie, maar eerder 'n gebalanseerde figuur, wat "'n rapsie van die swart magie" in hom het (p. 46), maar ook 'n sin vir selfopoffering en dissipline.

Die eietydse Suid-Afrikaanse ekwivalent van die twee helde van die geskiedenis, Wauchope en De la Rey, is die kleurling Gert Garries. Hy openbaar soms, in moeilike situasies, iets van die genialiteit van De la Rey. Soos Wauchope, is hy nie 'n simplistiese swart of wit nar nie. Hy bots met die verkeerskonstabel La Grange, 'n tipiese wit nar, sowel as met die swart chauffeur, 'n tipiese swart nar. Garries is 'n pragmatis, wat geleer het om met die grille van die noodlot saam te lewe en 'n praktiese oplossing uit te werk. In sy onderhandelinge met Lady Jubilence verwissel hy gemaklik van rolle soos wat omstandighede verander. Hy veg vernuftig en vreesloos wanneer die swart chauffeur hom bedreig, maar hy is ook ' $n$ oorgewer wat weet wanneer dit onverstandig is om verder te baklei ( $p$. 49).

Garries kry later die filmrol van 'n Boerekryger, wat sy band met die oorlogsgeskiedenis versterk - 'n moderne De la Rey? Soos Wauchope die ondergeskikte van Methuen was, styg Garries ten slotte in die lugballon op as die ondergeskikte van lord Sudden, 'n duidelike Methuen-figuur (p. 180). Soos Wauchope, het Garries in die oomblikke net voor sy dood volkome helderheid, voordat hy sterf (soos Wauchope) as onskuldige offer van die beplanning van wit narre. 
Met die Garries-figuur kom Leroux die naaste aan die lewende mite waarna hy steeds in sy oeuvre op soek gebly het. Garries is nóg swart nar nóg wit nar, maar 'n pragmatiese verbinding van albei; hy is nie swart man of wit man nie, maar Suid-Afrikaner wat sy land innig liefhet (p. 48-49). In Leroux se laaste roman, Onse Hymie, is daar weer 'n Garries, 'n duidelike parallel met die Garries van Magersfontein. In Onse Hymie oorleef Garries die ramp, anders as in Magersfontein. Waar hy in Magersontein veral 'n Wauchope-figuur is, is hy in Onse Hymie (1982) 'n De la Rey, 'n geniale teken van hoop te midde van 'n geskiedenis van verwoesting.

\section{7. 'n Verrassende debuut}

In April 1998 het 'n debuut verskyn wat 'n verrassende rypheid en vertelvernuf openbaar: die roman Op soek na generaal Mannetjies Mentz deur Christoffel Coetzee. Dit handel oor Mannetjies Mentz en sy kommando wat, na die oorgawe van die Boere-generaals Prinsloo en Roux in die Oos-Vrystaat, gevange Boeresoldate bevry het en mettertyd ook as "wraakkommando" opgetree het en op verskriklike maniere Engelse soldate en Boere wat onwillig was om die stryd voort te sit, aan hul einde laat kom het.

Die boek bestaan uit vier dele. Die tweede en derde dele, waarin die fiktiewe figuur Mentz sentraal staan, word "geraam" deur die eerste en die laaste deel wat skynbaar blote historiese verslaggewing is, gesteun deur verwysings na historiese figure. Deur hierdie "tweeledige" struktuur word die roman stewig in die geskiedenis geanker, maar is dit ook meer as 'n historiese relaas. Die verhaal oor Mentz is gebaseer op die geskiedenis van Boerekommando's soos dié van Slegtkamp en Hindon, maar dit word verbreed tot 'n romanmatige ontbloting van die bose "tweede natuur" van die mens - sy gewelddadigheid en onbeheerste seksuele drif. Mentz is 'n universele figuur, 'n Elckerlijk, met die tipiese gebreke van die "mens" (Mentz), by name die "mannetjiesmens". Saam met hierdie ontbloting van die skadukant van die mens is daar ook 'n groot deernis met die gekwelde mens op soek na vergifnis en verlossing.

\section{Vroueskrywers oor die oorlog}

Oor die algemeen is die oorlogstema veral deur manlike skrywers behandel, met enkele uitsonderings soos T.C. Pienaar, Miemie Louw-Theron en Elsa Joubert. Vervolgens word die werk van twee vroueskrywers betrek waarin die Oorlog weliswaar nie 'n sentrale rol speel nie, maar tog op die agtergrond 'n beduidende aanwesigheid vorm.

In Die groot gryse (1968) van Anna M. Louw is die fokus op die karakter van Paul Kruger gevestig. Die perspektief is dié van Kruger as wyse ou man in Clarence, en die sentrale tema is sy loutering tot "begrip-met-mededoë" (p. 271). 
Met hierdje begrip en mededoe is Kruger in staat om sy vyand, die Britse Ryk, wat sy eie ballingskap en die verlies van onafhanklikheid van die Boererepublieke veroorsaak het, te vergewe.

In die roman is daar ' $n$ volkome vereenselwiging met die dominante ideologiese tradisie van die tyd - ' $n$ verbinding van Christelike godsdiens, Afrikanernasionalisme en patriargie.

Daarenteen word Lettie Viljoen se Belemmering (1990) gekenmerk deur diepe onsekerheid en onrus. Die verhaal speel skynbaar in die onlangse verlede af, in die tyd van die bevrydingstryd teen die regering van daardie tyd. Die titel suggereer die tema van geskeidenheid: tussen man en vrou, tussen regering en onderdaan, tussen mens en God, en selfs tussen dié wat 'n gemeenskaplike vryheidstryd stry.

Veral opvallendheid is die geskeie wêrelde van man en vrou. Hannah doen navorsing in paleontologie in 'n Kaapse museum; haar gewese man is skynbaar deel van die groep manne wat in die berge besig is met die beplanning van die stryd teen 'n outokratiese heerser. Die private ruimte van die vrou, waarin moederskap en liefde prominent is, en die mannewêreld van aksie is volkome van mekaar geskei.

Die mans vertel onder mekaar stories uit die Anglo-Boereoorlog waarin die heldhaftigheid en vernuf van generaal De Wet na vore kom. Hul stryd van die hede kontrasteer sterk met die Boere se stryd van die verlede; De Wet se heroïek en doelgerigtheid staan teenoor hul eie stryd, wat dikwels byna die gedaante van 'n "cowboy en crooks"-speletjie aanneem. Dit is veelseggend dat, gepaard met 'n vertelling oor generaal De Wet se heldedade, die nuus bekend gemaak word dat een van die mans in die berge homself opgehang het (p. 233). In Belemmering word sowel die stryd van die vrou om medemenslike kontak as dié van die man om politieke bevryding, sterk gekenmerk deur frustrasie en mislukking.

\section{Jongste ontwikkelinge}

Dit lyk of die komende herdenking van die Anglo-Boerooorlog die stimulus vir allerlei verhale oor die oorlog is. So word byvoorbeeld romans oor die Oorlog deur Karel Schoeman, A.H.M. Scholtz en Eleanor Baker in die vooruitsig gestel. Verder beplan Van Schaik 'n publikasie met nuwe oorlogsverhale deur hedendaagse skrywers. Miskien is hierdie boeke die eerste tekens van 'n hernude belangstelling in 'n aangrypende stuk geskiedenis wat deur elke nuwe geslag opnuut geinterpreteer sal moet word.

\section{Bibliografie}

Coetzee, Christoffel. 1998. Op soek na generaal Mannetjies Mentz. Kaapstad : Queillerie. 
De Waal, J.H.H. 1933 [1912]. Die tweede Grieta. (4de druk). Kaapstad : Nasionale Pers.

Du Toit, F.G.M. 1948. Leipoldt in twee vergete oorlogsketse. In: Nienaber, P.J. C. Louis Leipoldt. Eensame veelsydige. Johannesburg : Afrikaanse Pers-Boekhandel. p. 262-270.

Joubert, Elsa. 1995. Die reise van Isobelle. Kaapstad : Tafelberg.

Joubert, G.J. 1938. Jaap kan nie verstaan nie. In: Joubert, G.J. Steiltes. Kaapstad : Nasionale Pers. p. 159-174.

Leipoldt, C.L. 1900. De rebel. Elseviers Geillustreerde Maandblad, 10(12):554-561, Des

Leipoldt, C L. 1901. Bambinelino. Elseviers Geillustreerde Maandblad, 11(11):784-791, Nov.

Leroux, Etienne. 1976. Magersfontein, o Magersfontein! Kaapstad : Human \& Rousseau.

Louw, Anna M. 1968. Die groot gryse. Kaapstad : Tafelberg.

Louw, N.P. van Wyk. 1938. Oorlogstories. Die Jongspan: 4, 8, Maart 4.

Louw-Theron, Miemie. 1935. ' $n$ Wiel binne ' $n$ wiel. Kaapstad : Nasionale Pers.

Malherbe, D.F. [1913] 1922. Vergeet nie. (4de druk). Bloemfontein : Nasionale Pers.

Marais, Eugéne [1934] 1939. Afrikanerbeeste. (4e druk). In: Marais, E. Die leeus van Magoeba. Pretoria : Van Schaik. p. 7-30.

Mikro. 1971 [1964]. Die ruiter in die nag. Kaapstad: Tafelberg.

Pienaar, T.C. 1937. 'n Merk vir die eeue. Kaapstad : Nasionale Pers.

Preller, Gustav. 1923. Oorlogsoormag en ander sketse en verhale. Kaapstad : Nasionale Boekhandel.

Reitz, J. 1927. Wraak. Kaapstad : Nasionale Pers. (Almal se boeke, nr. 17.)

Schoonees, P C. 1939. Die prosa van die Tweede Afrikaanse Beweging. (3de gewysigde druk). Pretoria : De Bussy

Smuts, J.P. 1997. Die nuwe herinneringsliteratuur in Afrikaans Stilet, 9(2):1-8.

Stemmet, J.F. 1975. Die insameling van outobiografiese getuienisse oor die AngloBoereoorlog. Christiaan de Wet-Annale, 3:105-122.

Steyn, Fritz. 1941. Die Penkop-kommando. Johannesburg : Voortrekkerpers.

Steyn, J.C. 1976. Vrede. In: Steyn, J.C. Op pad na die grens. Kaapstad : Tafelberg. p. 53-59.

Steyn, J.C. 1987. Trouwe Afrikaners. Kaapstad : Tafelberg.

Steyn, J.C. 1992. Vet en maer jare. In: Beukes, W.D. (red.) Boekewêreld. Kaapstad Tafelberg. p. 86-115.

Tomlinson, G. 1917. Deur die smeltkroes. Kaapstad : Nasionale Pers.

Van Bruggen, J.R.L. 1935. Bittereinders. Potchefstroom : Huyser.

Van Bruggen, J.R.L. 1943 [1942]. Die gerig. (2de druk). Pretoria : Unie-Boekhande].

Van Bruggen, Jochem. [1918] 1930. Teleurgestel. (4de druk). Pretoria : Van Schaik.

Van Coller, H P. 1997. Die Waarheidskommissie in die Afrikaanse letterkunde: Die Afrikaanse prosa in die jare negentig. Stilet, 9(2):9-21.

Van den Heever, Toon. [1948] 1958. Gerwe uit die erfpag van Skoppensboer. (5de druk). Johannesburg : Afrikaanse Pers-Boekhandel.

Van der Merwe, C.N. 1998. Waarheid en versoening by Van Melle se drie Joiners. Stilet, 10(1):35-42.

Van Melle, Johannes. 1943. Wraak. In: Van Melle, J. Begeestering. Kaapstad : Nasionale Pers. p. 3-52.

Viljoen, J.M.H. 1953. 'n Joernalis vertel. Kaapstad : Nasionale Boekhandel.

Viljoen, Lettie. 1990. Belemmering. Emmerentia : Taurus 
